\title{
Two Portraits of Senenmut in the Hatshepsut Temple at Deir el-Bahari
}

\author{
MirosŁaW BARWIK
}

\begin{abstract}
Two graffiti of Senenmut from the Temple of Hatshepsut at Deir el-Bahari are presented in this paper: one located in the granite portal leading to the Upper Court of the temple, and another in the entrance to the Chapel of Thutmose I in the Royal Mortuary Cult Complex. In addition, photographs of heavily erased graffiti of Senenmut in the entrance to the Chapel of Hatshepsut are published here as well.
\end{abstract}

Keywords: New Kingdom Egypt, Deir el-Bahari, Temple of Hatshepsut, Senenmut

Mirosław Barwik, Faculty of Archaeology, University of Warsaw, Warsaw; mbarwik@uw.edu.pl;

(iD) 0000-0002-1389-7457

There are traces of over sixty portraits of Senenmut in the doorways and niches of the Temple of Hatshepsut at Deir el-Bahari. ${ }^{1}$ Only four of these images have been left intact, and these are located in the niches of the Hathor chapel (Fig. 1). ${ }^{2}$ In most instances, the relief had originally been painted in yellow, which is the case of the images made on the limestone walls. Only one portrait, carved in red granite was painted in green, and was situated on the left (southern) doorjamb of the gate leading to the Upper Court of the temple, just above the socket of the door bolt (preserved remnants of inscription are $c .1 .86 \mathrm{~m}$ above the threshold, and c. $0.25 \mathrm{~m}$ from the western face of the doorjamb). ${ }^{3}$ The representation in question has been completely erased to the effect that only tiny traces of the hieroglyphic signs are visible now. Of the figure of Senenmut himself, only remnants of one arm raised in a gesture of adoration are preserved, while the rest of the representation has been completely destroyed. The accompanying text can be read as follows (cf. Fig. 2):

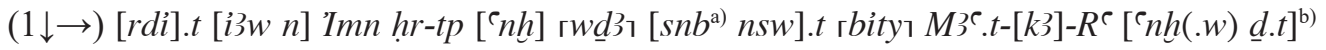
$(2 \rightarrow) i[n \ldots]$

${ }^{1}$ Cf. Winlock 1942: 105-106; Hayes 1957: 80-84; Meyer 1982: 200.

2 Cf. Meyer 1982: 200; Beaux 2012: 191-192; Beaux et al. 2012: Pls 64-67.

${ }^{3}$ Not recorded in $\mathrm{PM} \mathrm{II}^{2}, 357$; Naville 1906: 2 (description of the gate); incorrectly recorded in: Iwaszczuk 2016: 123, Fig. 20. 


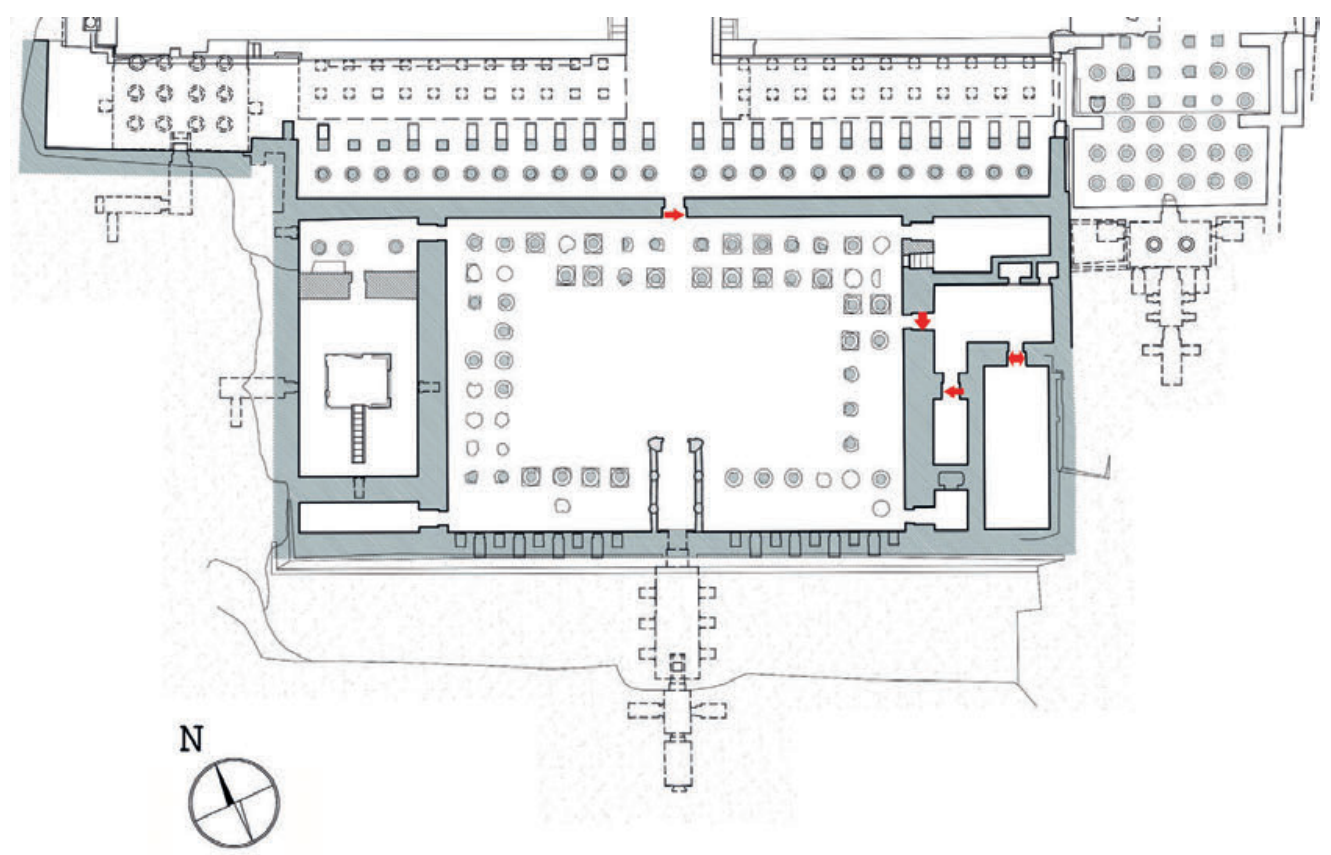

1. Location of Senenmut's graffiti commented in the text (Drawing: T. Dziedzic).

a) For the meaning of the formula $h r-t p{ }^{`} n h w d \underline{d}$ s snb, see: Kopp 2003.

b) This is a preserved trace of what seems to be the $t$ sign, which prevents us from reading here 'nh.ti, as in some other recorded examples. ${ }^{4}$ There is no space whatsoever to fit the group ‘nh.ti d.t.

'(1) [Giv]ing [praise to] Amun on behalf of [the life], 「prosperity?, [and health of the king of Upper] and rLower Egypt` Maat-[ka]-Re, [may he live forever], (2) b[y ...]'.

Nothing has remained of the name or titles of Senenmut. It is possible, however, that a shorter version of the text had been inscribed here due to the restricted space above Senenmut's raised hands. ${ }^{5}$ As in other shorter versions of the text, one can restore here perhaps: i [n imy-r pr Sn-(n)-Mwt], 'b[y the steward Senenmut]'. ${ }^{6}$

The inscription left in the entrance to the so-called Northern Chapel of Amun ${ }^{7}$ has a special significance as regards the meaning of all these representations of the influential official. It states unambiguously that it was a royal favour that enabled Senenmut 'to let his

${ }^{4}$ Cf. e.g. Hayes 1957: Fig. 1 [H].

${ }^{5}$ It seems that the text had been inscribed here in a horizontal line, as in the case of the second Senenmut's graffito presented here.

${ }^{6}$ Cf. Hayes 1957: Fig. 1 [G, H, K, L].

${ }^{7}$ Hayes 1957: 80-84, Figs 2-3; cf. also Meyer 1982: 201, 327 (text no. 16). 


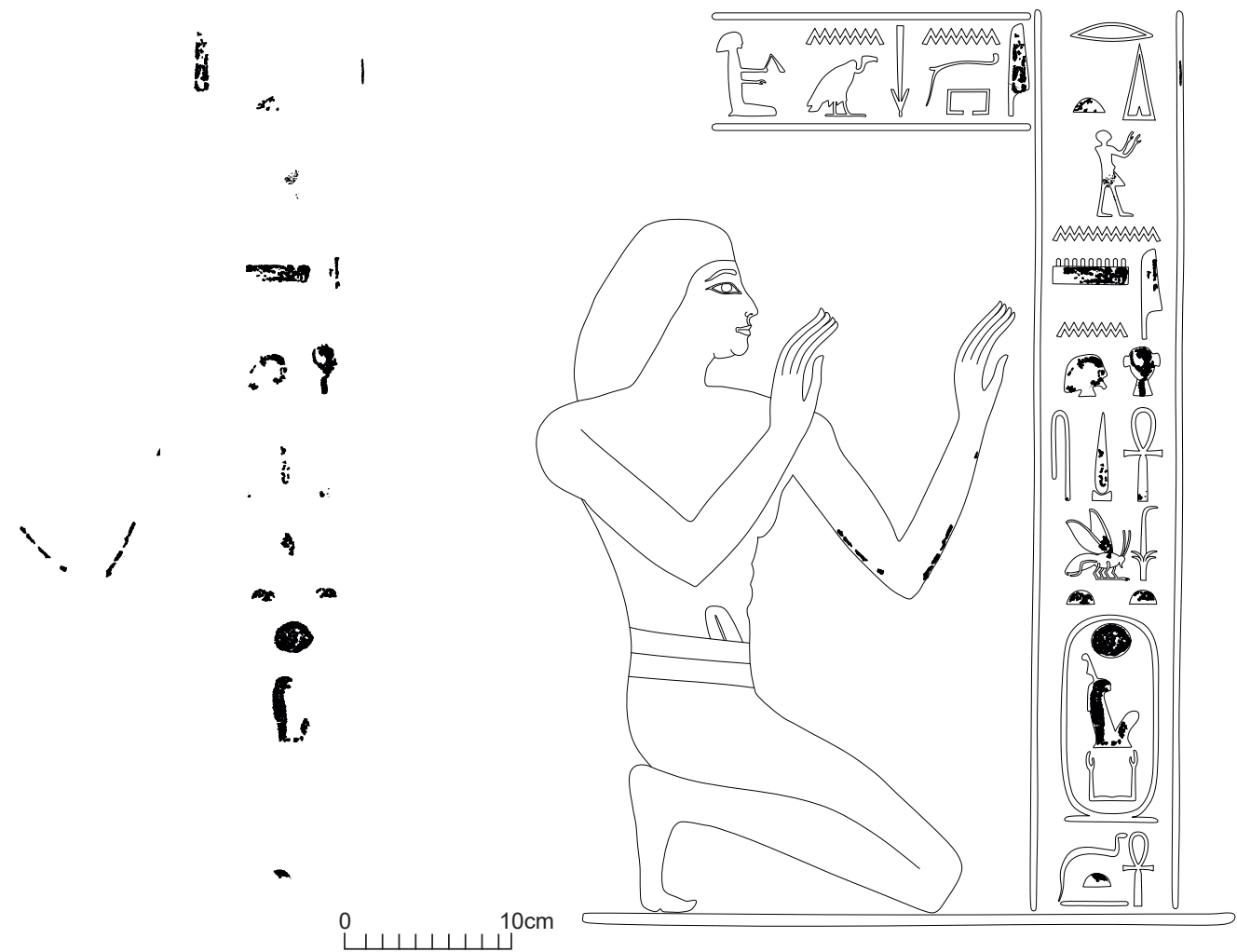

2a. Remnants of Senenmut's erased graffito on the southern jamb of the granite portal leading to the Upper Court of the temple; b. restoration (Drawing and digitising: M. Czerniec, M. Puszkarski, K. Kasprzycka).

name be established on every wall in the following of the king in Djeser-djeseru' (cols 2-4). There can be no doubt, that it was Thuthmose III who ordered all these inscriptions and representations to be erased, together with accompanying cartouches of Hatshepsut, written usually in this context. ${ }^{8}$ It is noteworthy that only once was it the cartouche of Thutmose I that had been written in the frame of Senenmut's prayer (see below), and it was also treated crudely in the same way.

The more or less complex adoration formulas or prayers that accompany Senenmut's representations in the temple may be related perhaps to the cultic function of the chapels in question. This is also the situation in the case of such representations placed

${ }^{8}$ Cf. Dorman 1988: 156-157, 173, n. 52; for a contrary view, i.e. a persecution of Senenmut's memory still before the death of Hatshepsut, see, e.g. Switalski Lesko 1967; Meyer 1982: 264-273; it is possible, however, that the erasures of Senenmut's graffiti in the Hatshepsut temple need not be related necessarily to other acts of damnatio memoriae inflicted on Senenmut. An idea of Amarna iconoclasm standing behind these erasures (cf. Schulman 1969-1970) cannot be substantiated. 


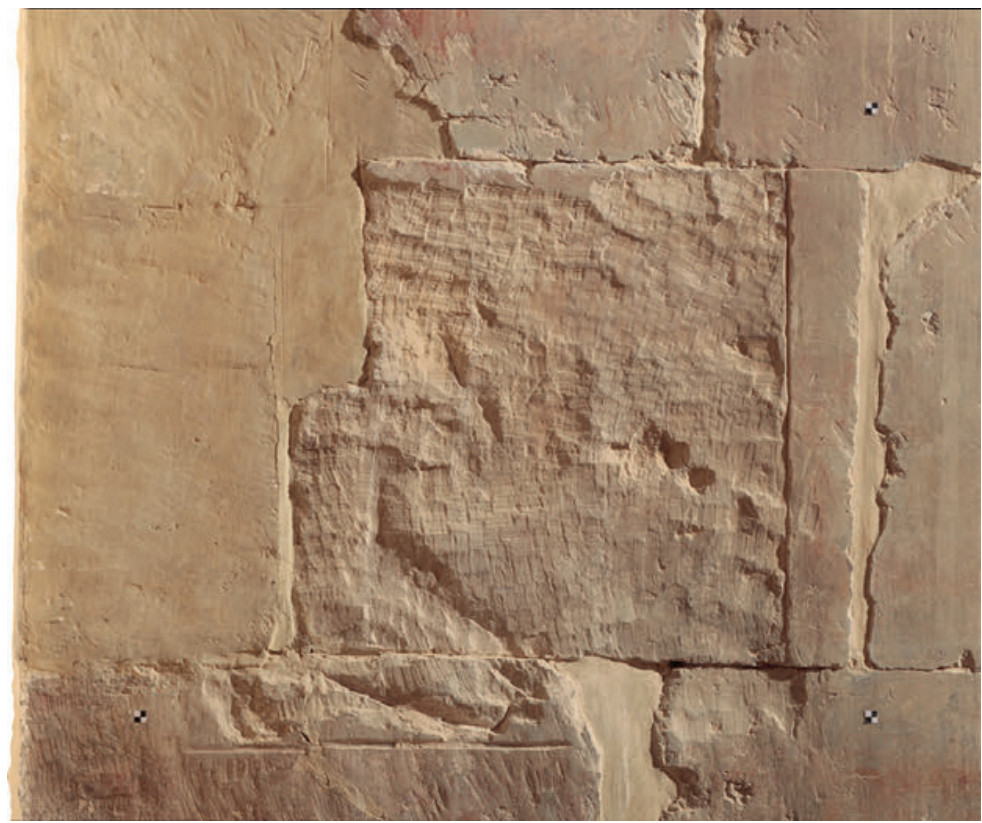

3. Senenmut's image on the southern reveal of the doorway leading into the Chapel of Hatshepsut - remnants of one arm and leg are visible; to the right a line demarcating a column of inscription; no traces of hieroglyphs preserved (Phot. M. Caban).

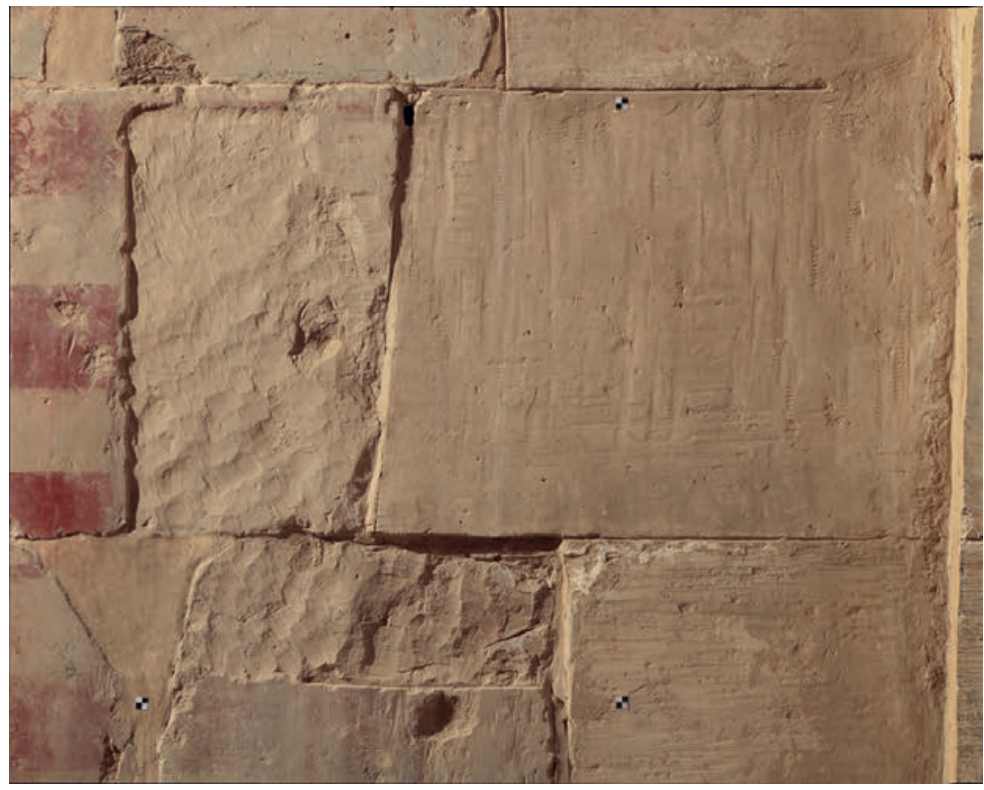

4. Senenmut's image on the northern reveal of the doorway leading into the Chapel of Hatshepsut - only the lower part of a leg and a trace of a hand are visible; to the left a line demarcating a column of inscription; no traces of hieroglyphs preserved (Phot. M. Caban). 
in the Royal Mortuary Cult Complex: on the western undecorated wall of the entrance to the complex, ${ }^{9}$ and in the doorways of two its chapels - that of Hatshepsut (on both doorjambs; cf. Figs 3-4), ${ }^{10}$ and Thutmose I. Only tiny traces of Senenmut's kneeling figure are preserved in the first three instances, but the image on the northern reveal of the doorway leading into the chapel of Thutmose I (Figs 5-6) can be restored in its entirety. ${ }^{11}$ It was located $1.27 \mathrm{~m}$ above the threshold. Traces of yellow paint covering the hieroglyphs and the figure of Senenmut are preserved. Enough has been preserved indeed to notice the high quality of the workmanship of the original relief. One can recognise here the kneeling figure of Senenmut turned left towards the chapel interior, with his hands raised in gesture of homage (the scheme adopted in other preserved examples). The accompanying text can be read as follows:

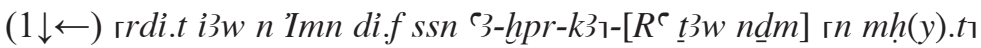
$(2 \leftarrow)$ rin imy-r pr $S n-(n)-M w t_{1}$

'(1) rGiving homage to Amun that he cause that Aa-kheper-ka?-[Re] would smell [the sweet breath] rof the northern breeze; (2) by the steward Senenmut?'.

No doubt, the mention of the northern breeze reflects here the name of the portal leading into the chapel: ${ }^{12} s b 3{ }^{C 3}-h p r-k 3-R^{\complement}[\operatorname{Imn} d d m h(y) . t],{ }^{13}$ 'The gate of Aa-kheper-ka-Re: [Amun who gives the (breath of) north wind] ${ }^{14}{ }^{14}$ as apparently no other inscription in the temple, accompanying Senenmut, mentions it. Compare also the 'sweet breeze of life' mentioned in one of the inscriptions on the west wall of the Chapel of Thutmose I (unpublished). Obviously, one cannot ignore the fairly common appearance of the northern breeze in the offering formulas of the period. ${ }^{15}$ Significantly, the 'sweet breeze' appears in the Book of the Dead chapter $56,{ }^{16}$ being a part of the compilation of the text of the First Hour of Night, inscribed on the western tympanum in the nearby Chapel of Hatshepsut. ${ }^{17}$

\section{Acknowledgements}

I am grateful to Paul Barford for revising my English.

${ }^{9}$ Cf. Iwaszczuk 2016: 203; no traces of inscription preserved.

${ }^{10}$ Cf. Iwaszczuk 2016: 211; no traces of inscription preserved.

${ }^{11}$ For this graffito cf. PM II², 361 [104d]; Iwaszczuk 2016: 217; Winlock 1942: Pl. 45 (upper, left); Hayes 1957: Fig. 1 [L]; Schulman 1969-1970: 46; Meyer 1982: 200.

${ }^{12}$ Cf. Hayes 1957: 82, n. 4.

${ }_{13}$ Restored in antiquity after the Amarna erasures.

${ }^{14}$ Compare: Naville 1906: 6; Grothoff 1996: 113, 115, 466 (Doc. 6); translated in another way by Iwaszczuk 2011: 114. No traces of re-carving the first line of the inscription are visible, so the rather vague suppositions signaled by Grothoff and Iwaszczuk remain incomprehensible.

${ }^{15}$ Cf. Barta 1968: 93 ('Bitte' 78 and 79).

${ }_{16}$ Naville 1886: 125; compare also CT Spell 222: De Buck 1947: 207.

17 Naville 1901: Pl. 115; cf. also Griffin 2017: 115. 

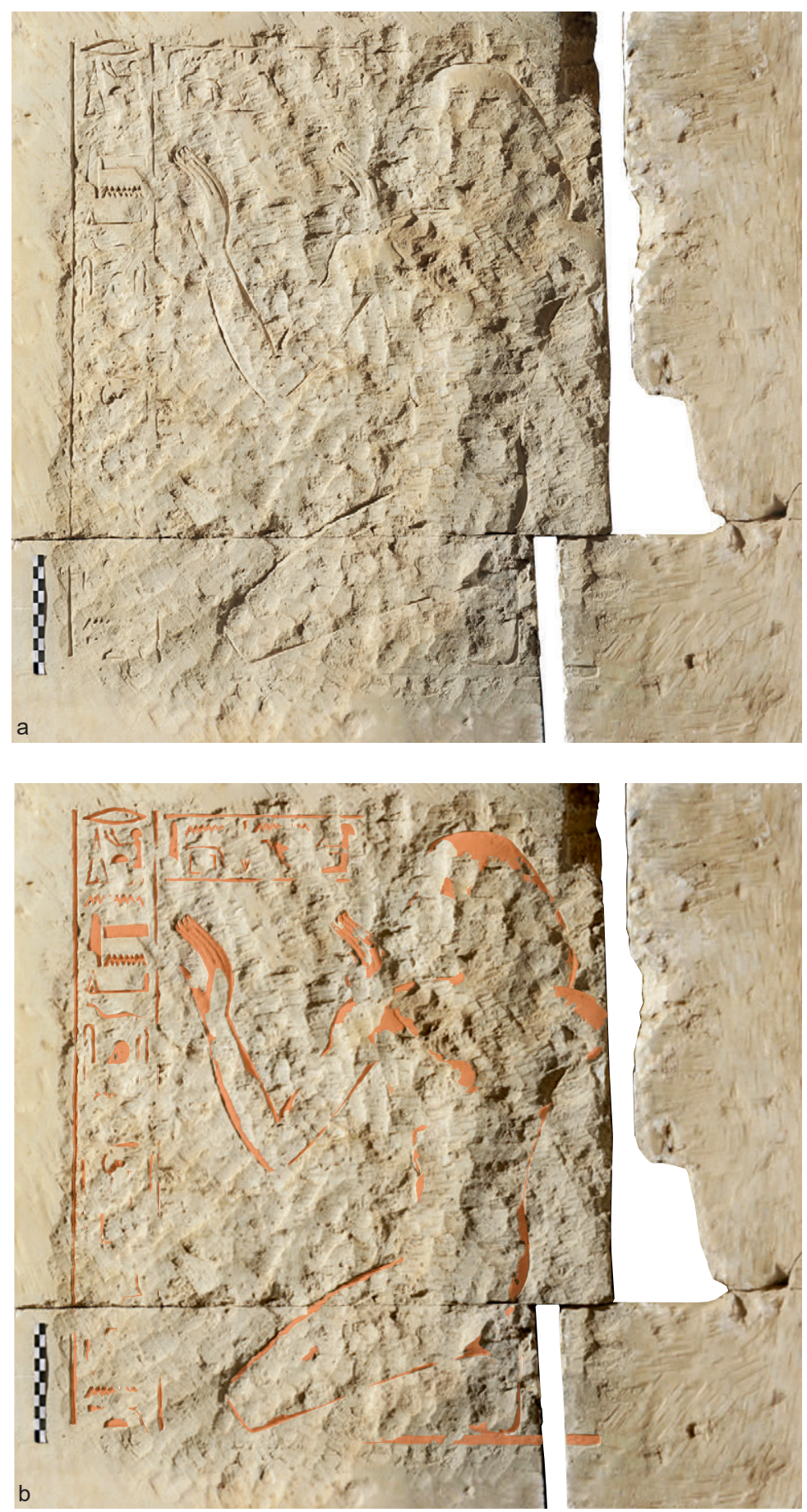

5a-b. Senenmut's image in the entrance to the Chapel of Thutmose I (Phot. M. Caban; drawing: M. Puszkarski). 
6. Restoration of Senenmut's image in the entrance to the Chapel of Thutmose I (Drawing: M. Puszkarski).

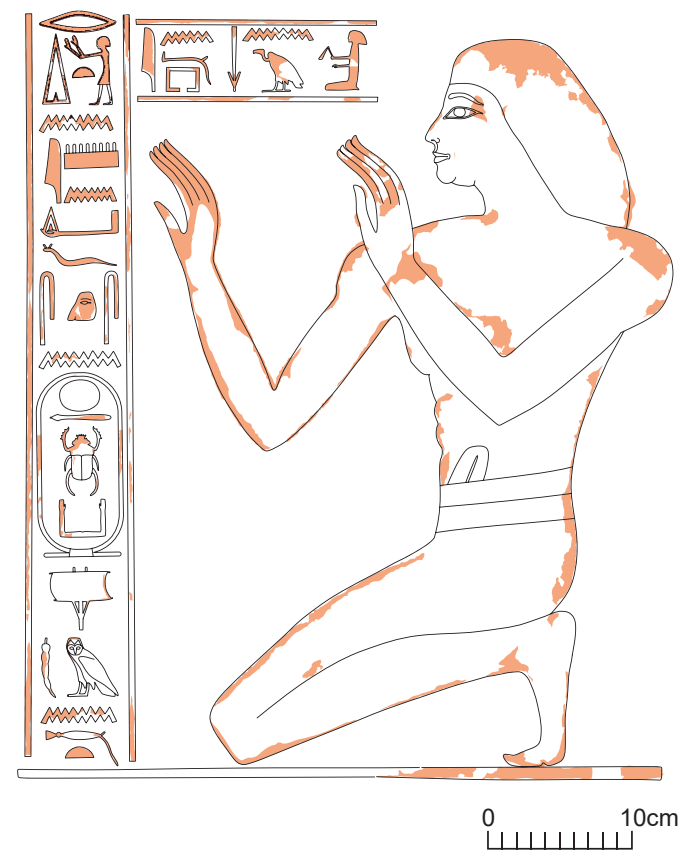

\section{References}

Barta, W. 1968: Aufbau und Bedeutung der altägyptischen Opferformel, ÄgForsch 24, Glückstadt-Hamburg-New York

Beaux, N. 2012: La chapelle d'Hathor. Temple d'Hatchepsout à Deir el-Bahari I. Vestibule et sanctuaires, fasc. 1 : Texte, MIFAO 129/1, Le Caire

Beaux, N., Karkowski, J., Majerus, E., Pollin, G. 2012: La chapelle d'Hathor. Temple d'Hatchepsout à Deir el-Bahari I. Vestibule et sanctuaires, fasc. 3 : Planches, MIFAO 129/3, Le Caire

Buck, A. de 1947: The Egyptian Coffin Texts III. Texts of Spells 164-267, OIP LXIV, Chicago

Dorman, P.F. 1988: The Monuments of Senenmut: Problems in Historical Methodology, Studies in Egyptology, London-New York

Griffin, K. 2017: Toward a better understanding of the Ritual of the Hours of the Night (Stundenritual), [in:] Pischikova, E. (Ed.), Tombs of the South Asasif Necropolis. New Discoveries and Research 2012-14, Cairo-New York-London, 97-134

Grothoff, T. 1996: Die Tornamen der ägyptischen Tempel, AegMonast 1, Aachen Hayes, W.C. 1957: Varia from the Time of Hatshepsut, MDAIK 15, 78-90

Iwaszczuk, J. 2011: The Names of the Construction Parts in the Temple of Hatshepsut at Deir el-Bahari. Question of Erasures of the Feminine Endings, EtudTrav XXIV, $109-115$ 
Iwaszczuk, J. 2016: Sacred landscape of Thebes during the reign of Hatshepsut. Royal construction projects. Volume 2. Topographical bibliography of the West Bank, Travaux de l'Institut des Cultures Méditerranéennes et Orientales de l'Académie Polonaise des Sciences 3, Warsaw

Kopp, E. 2003: Der Pharao erhält die Gunst. Der Gebrauch von $h r-t p$ ' $n h \underline{w} w \underline{d} 3$ snb, GöttMisz 197, 49-53

Meyer, Ch. 1982: Senenmut. Eine prosopographische Untersuchung, Ḧ̈S 2, Hamburg

Naville, É. 1886: Das Aegyptische Todtenbuch der XVIII. bis XX. Dynastie, vol. II, Berlin

Naville, É. 1901: The Temple of Deir el-Bahari. Part IV. The Shrine of Hathor and the Southern Hall of Offerings, MEEF 19, London

Naville, É. 1906: The Temple of Deir el-Bahari. Part V. The Upper Court and Sanctuary, MEEF 27, London

Schulman, A.R. 1969-1970: Some Remarks on the Alleged "Fall" of Senmūt, JARCE VIII, 29-48

Switalski Lesko, B. 1967: The Senmut Problem, JARCE VI, 113-118

Winlock, H.E. 1942: Excavations at Deir el-Bahri, 1911-1931, New York 


\section{ÉTUDES et TRAVAUX XXXIII / 2020}
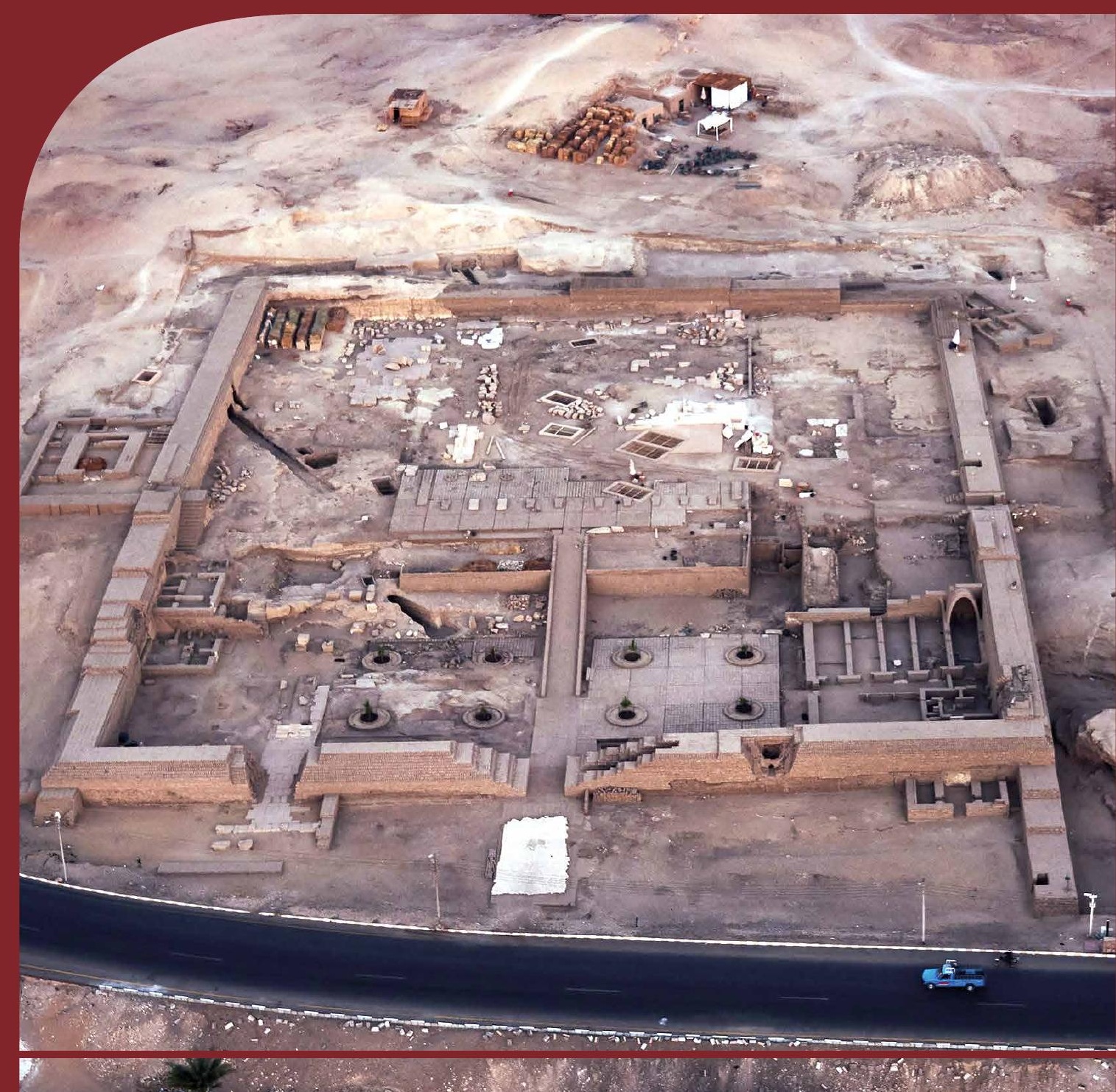

BOPIKSiO Institut des Cultures Mediterranéennes et Orientales IST PAN de l'Académie Polonáise des Sciences 


\title{
COMITÉ DE RÉDACTION SCIENTIFIQUE
}

Maciej Makowski - rédacteur en chef Jadwiga Iwaszczuk - rédacteur

Agnieszka Ryś - secrétaire de la rédaction

Ewa Laskowska-Kusztal - rédacteur thématique du volume

CONSEIL SCIENTIFIQUE DU JOURNAL

Michał Kobusiewicz (IAE PAN, Warszawa)

Ewa Laskowska-Kusztal (IMOC PAS, Warszawa)

Demetrios Michaelides (University of Cyprus, Nicosia)

Jean-Charles Moretti (IRAA-MOM, Université de Lyon 2/CNRS)

Dietrich Raue (Ägyptisches Museum der Universität Leipzig)

Paul Reynolds (ICREA, España)

Derek Welsby (British Museum, London)

COMITÉ SCIENTIFIQUE DE LECTURE

la liste des membres du comité est accessible en ligne sur

http://www.etudesettravaux.iksiopan.pl

\author{
RÉDACTION TECHNIQUE \\ Jadwiga Iwaszczuk \\ Maciej Makowski
}

REVUE DES TEXTES EN ANGLAIS

Jo Harper 
ÉTUDES et TRAVAUX XXXIII 
INSTYTUT KULTUR ŚRÓDZIEMNOMORSKICH I ORIENTALNYCH POLSKIEJ AKADEMII NAUK

\title{
STUDIA i PRACE
}

XXXIII

\author{
ROIKŚSiO \\ ESOPAN \\ WARSZAWA \\ 2020
}


INSTITUT DES CULTURES MÉDITERRANÉENNES ET ORIENTALES DE L'ACADÉMIE POLONAISE DES SCIENCES

\section{ÉTUDES et TRAVAUX}

XXXIII

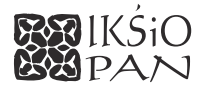

VARSOVIE

2020 
Publication scientifique financée dans le cadre du programme du Ministre de la Science et de l'Éducation Supérieure

« Programme National de Développement de l'Humanistique » pour les années 2016-2021 (projet no 3bH 150099 83)

\title{
UARODOWY PROGRAM ROZWOJU HUMANISTYKI
}

\author{
Copyright (C) \\ Instytut Kultur Śródziemnomorskich i Orientalnych PAN \\ et les Auteurs \\ Warszawa 2020
}
ISSN 2084-6762
(jusqu'en 2011 : 0079-3566)
e-ISSN 2449-9579
Version première en papier, imprimée en Pologne - 150 copies
Version électronique accessible sur
http://www.etudesettravaux.iksiopan.pl

Édition: Polskie Towarzystwo Historyczne et Wydawnictwo Neriton, Warszawa

Conception générale de la couverture : J. Iwaszczuk

Photographie de couverture : J. Pablo Moreira (C) Thutmosis III Temple Project

(Henket-ankh, le temple des Millions d'Années de Thoutmosis III, Louxor) 


\section{Table des matières}

Editorial (par Ewa Laskowska-Kusztal) ................................................................... 7

MirosŁaW BARWIK

Two Portraits of Senenmut in the Hatshepsut Temple at Deir el-Bahari

MirosŁaW BARWIK

New Prayers and Invocations to Hathor among Unpublished Dipinti

from the Thutmose III Temple at Deir el-Bahari

LiNDA CHAPON

The Decoration of the Columns and Pillars from the Henket-ankh of Thutmose III

(Western Thebes)

Abraham I. Fernández Pichel

Quelques blocs ptolémaïques inédits de la cour du IX pylône du domaine

d'Amon à Karnak

Amgad Joseph

The Stela of Haremwia, Chief of the Provisioning Sector of the Temple Workshop

(CG 34079 / JE 22011)

EWA JÓZEFOWICZ

Ramesside Inscriptions and Preparatory Sketches in the Western Wall of Portico

of Obelisks of Hatshepsut's Temple at Deir el-Bahari

Miral LASHIEN

Donkeys in the Old and Middle Kingdoms According to the Representations

and Livestock Counts from Private Tombs

AleKsandra Pawlikowska-Gwiazda

Christian Secondary Epigraphy in the Temple of Hatshepsut. Some New Remarks

KRZYSZTOF RADTKE

Square Grids in the Tomb of Akhethotep - Questions and Doubts

Myriam Seco Álvarez, JaVier Martínez Babón

The Temple of Millions of Years of the Pharaoh Thutmose III (Luxor). An Update on the Research 